\title{
Constituting Our Constitution, Constituting Ourselves: Comments on Reva Siegel's Constitutional Culture, Social Movement Conflict and Constitutional Change
}

\section{Citation}

Martha Minow, Constituting Our Constitution, Constituting Ourselves: Comments on Reva Siegel's Constitutional Culture, Social Movement Conflict and Constitutional Change, 94 Calif. L. Rev. 1455 (2006).

\section{Published Version}

http://scholarship.law.berkeley.edu/californialawreview/vol94/iss5/4/

\section{Permanent link}

http://nrs.harvard.edu/urn-3:HUL.InstRepos:12933361

\section{Terms of Use}

This article was downloaded from Harvard University's DASH repository, and is made available under the terms and conditions applicable to Other Posted Material, as set forth at http:// nrs.harvard.edu/urn-3:HUL.InstRepos:dash.current.terms-of-use\#LAA

\section{Share Your Story}

The Harvard community has made this article openly available.

Please share how this access benefits you. Submit a story.

\section{Accessibility}




\section{California Law Review}

Volume 94 | Issue 5

Article 4

October 2006

\section{Constituting Our Constitution, Constituting Ourselves: Comments on Reva Siegel's Constitutional Culture, Social Movement Conflict and Constitutional Change}

Martha Minow

Follow this and additional works at: http://scholarship.law.berkeley.edu/californialawreview

\section{Recommended Citation}

Martha Minow, Constituting Our Constitution, Constituting Ourselves: Comments on Reva Siegel's Constitutional Culture, Social Movement Conflict and Constitutional Change, 94 CAL. L. REv. 1455 (2006).

Available at: http://scholarship.law.berkeley.edu/californialawreview/vol94/iss5/4 


\title{
Constituting Our Constitution, Constituting Ourselves: Comments on Reva Siegel's Constitutional Culture, Social Movement Conflict and Constitutional Change
}

\author{
Martha Minow $\dagger$
}

Powerfully resonating with the life of the Justice whose center hosts this lecture, Reva Siegel's important Brennan Lecture interprets key historical experiences in order to help us understand how democracy and constitutionalism can and do connect. Siegel channels Justice Brennan's good cheer when she recasts our failure to amend the Constitution to prohibit sex-based discrimination as not only a de facto success, but also as an illustration of a vibrant constitutional culture. Like Justice Brennan, who had an uncanny ability to make each interlocutor feel uniquely heard and important, Siegel offers each reader the role of potential constitutional refresher: we each can play a role in the social movements and countermovements that revitalize constitutional meaning. Despite Siegel's explicit claim that hers is a modest enterprise, we find ourselves blinking in the brightness of a re-envisioned constitutional landscape.

I will first restate her central argument, and then ask two questions. Professor Siegel identifies social movements as central channels in the navigation between the sometimes divergent goals of self-government and legal order. Social movements construct informal pathways for democratic responsiveness by debating Supreme Court nominations and proposing largely unsuccessful constitutional amendments. In this process, people-"The People"-contribute to the project of constitutional interpretation.

Siegel asserts that by using these informal pathways as focal points of self-government, social movements revitalize the Constitution. By participating in rallies, giving and attending speeches, proposing even successful

Copyright (C) 2006 California Law Review, Inc. California Law Review, Inc. (CLR) is a California nonprofit corporation. CLR and the authors are solely responsible for the content of their publications.

$\dagger \quad$ Jeremiah Smith, Jr. Professor of Law, Harvard Law School. 
constitutional amendments, wearing t-shirts and writing elected representatives, participants can address their arguments about constitutional meaning to both fellow citizens and government officials. ${ }^{1}$ Siegel's story emphasizes the democratic significance of what she calls "identity formation and deliberation."2 For example, as people participate in a social movement advocating rights for members of racial minorities or women, they claim and simultaneously help to construct self-understandings as members of particular groups and as people entitled to recognition and rights based on that membership. At the same time, their discussions and arguments within and beyond their own group generate priorities and norms. Movements connect practical questions with symbolism in order to motivate people to political action such as voting, passing out leaflets, displaying a bumper sticker, joining a public demonstration, and donating money or time to the cause.

Siegel's boldest claim is that the pathways to constitutional participation she identifies actually discipline democratic participation by requiring speech instead of violence. The specific demand is to use constitutional speech. Its use, in turn, strengthens both self-government and the Constitution. The norms and practices of constitutional speech demand that people appeal to shared commitments already present in our constitutional understandings, and that they pay respect to legal authorities and rule of law values. ${ }^{3}$ These constraints channel conflict to ensure that it "vitalize[s] rather than undermine[s] the system,", and promotes social integration. Siegel offers examples of her theory in action in the movement for the Equal Rights Amendment and for the Nineteenth Amendment. As she does so, Siegel beautifully renders portraits of Pauli Murray, Tom Emerson, Betty Friedan, Sylvia Law, Phyllis Schlafly, and the young Ruth Bader Ginsburg, portraits worthy of hanging alongside those of the more familiar shapers of our Constitution. But these portraits are of the sort J.K. Rowling devised in the Harry Potter books: portraits whose subjects can move, converse, and visit one another within their separate frames.

Now, on to my two questions. First, are the narratives Siegel creates, and the pathways they travel, really constitutional law, or instead are they politics? Siegel emphasizes the fact that mobilized citizens use elections and other means when officials diverge too far from the views held by

1. "Because exercises of constitutional lawmaking play a restricted role in the American constitutional order-the United States Constitution has been amended less than twenty times since the founding-the system needs institutions that enable popular engagement with questions of constitutional meaning to ensure its continuing democratic authority," Reva B. Siegel, Constitutional Culture, Social Movement Conflict and Constitutional Change: The Case of the de facto ERA, 94 CALiF. L. REV. 1323, 32 (2006).

2. Id. at 1341 .

3. Id. at 1418 .

4. Id. 
most Americans. ${ }^{5}$ What makes this an avenue of constitutional law, rather than simply politics? Siegel's reply is "semantic constraint," through which people need to convert, in Siegel's felicitous phrase, "challenges to the constitutional order ... into challenges OF the constitutional order."

Yet even this seems a condition of as much politics and culture as law. Social critics work within a culture's traditions, as Michael Walzer's work shows. ${ }^{7}$ Early reformers like Elizabeth Cady Stanton positioned themselves simultaneously as interpreters of legal texts, religious texts, and life experience; they interpreted old sources in order to persuade. ${ }^{8}$ The enterprise of persuasion fundamentally depends upon convincing the listener that your argument connects with something he or she already believes to be true or a value he or she wants to be known to share. ${ }^{9}$ Legal argument turns this truism into professional practice. But this fact does not convert all acts of persuasion into legal reform, nor all legal reform efforts into attempts to change constitutional meaning.

Appealing to a set of ideas or concepts in order to persuade others may carry limitations of logic or coherence. Historian Eric Foner has written about how the reliance on the tradition of self-ownership by Abolitionists ultimately limited the remedies they could pursue during Reconstruction, for the same root concepts of private property ownership curbed any potential redistribution of property after the Civil War. Nonetheless, the self-ownership tradition resonated with non-activists and assisted the anti-slavery cause. ${ }^{10}$ But it is not the internal limitations of

5. "If the constitutional law that officials pronounced diverges too far from understanding to which American citizens subscribe, a mobilized citizenry knows how to hold judges and the elected officials who [appoint] them to account." Siegel, supra note I at 1419.

6. Id. at 1350 (cmphasis added).

7. Michael Walzer, Interpretation And Social Criticism (1987).

8. See Elizabeth Cady Stanton, Eighty Years and More: Reminiscences 1815-1897 (Shocken Books reprint 197I) (1898); Elizabeth Cady Stanton, The Woman's Bible (Coalition Task Force on Women and Religion reprint 1974) (I898); See also LoIS W. BANNER, ELIZABETH Cady Stanton: A Radical for Woman's Rights (1980) (reviewing Stanton's efforts to draw on legal, religious, and political sources); Martha Minow, Rights of One's Own 98 HARv. L. REv. I084 (1985) (rcviewing Elisabeth Griffith, IN Her OWN Right: The Life of Elizabeth Cady STANTON (1984)) (describing Stanton's use of varied arguments and sources).

9. See Richard Briffault, Our Localism: Part II - Localism and Legal Theory, 90 CoLUM. L. REV. 346, 394 ("since political issues are collective issues, individuals involved in politics will bc compelled to discuss, dcliberate and debate with each other. They will have to listen to each other's positions, learn the arts of persuasion and compromise"); Sherman 1. Clark, The Character of Persuasion, I Ave Maria L. Rev. 61 (2003) ("persuasive argument ... responds to the concerns and priorities of the ... [one to be persuaded]"); see also Jerry Frug, Argument as Character, 40 STAN. L. Rev. 869 (1988); Joseph William Singer, Persuasion, 87 MICH. L. Rev. 2442, 2458 (1989) (arguing that persuasion depends upon reaching listeners' values or connections with others).

I0. See Eric Foner, Reconstrution: America's Unfinished Revolution I 863-1977 (1988); See also Eric Foner, The Story of American Freedom (1998) (tracing rhctorical and political struggle for equality); ERIC Foner, Politics and Ideology in the Age of the Civil War (I980) (examining Republican ideology); Siegel, supra note I at 1359-60. ("The conditions of the 
various conceptions of gender equality so much as demands of political feasibility that punctuate Siegel's story of the ERA's advocates and opponents.

Perhaps legal semantics as conceived by Siegel constrain when couched as particular appeals to common tradition or shared membership. These kinds of appeals do seem to require a shift from the particular to the general, translating a partisan vision into a public value." This translation effort may, of course, be purely instrumental. But it may also have the psychological effect of drawing the advocate more firmly into allegiance with others seeking to attain similar legal or political transformations, taming dissent into affiliation, and converting " $\mathrm{I}$ " into "we." This is a feature of rights discourse that interests me. To assert a right, you have to lay claim to the community that recognizes that right. Paradoxically, this necessity can briefly turn seeming adversaries into a community of interest. ${ }^{12}$

But again, there is nothing that makes this concept notably constitutional, and perhaps not even specifically legal, given the potential sources of rights in politics, ethics, theology, and even community practice. Appeal to tradition, and you become, in some ways, more traditional. Stave off attacks on tradition, and you try, in some ways, to show that tradition is flexible. That said, the accounts of Phyllis Shlafly's gay-bashing and antiabortionism are reminiscent of the narratives of transformation and preservation detailed by Professor Siegel in her previous work, ${ }^{13}$ making us marvel at the continuity and circularity of gender politics.

Siegel's telling depiction of the mutual accommodations made by proand anti-ERA groups ${ }^{14}$ match the familiar dynamics not only of politics but also of mass markets. Going mainstream makes radicals more conservative. Fighting off compelling reformers requires meeting them partway, coopting them, or as Bill Clinton liked to call it, triangulating. ${ }^{15}$ It is not

Constitution's intelligibility constrain changes in its meaning, even without the intermediation of the state.").

11. Siegel, supra note 1 at 1359.

12. See Martha Minow, Interpreting Rights: An Essay for Robert Cover, 96 YALE LAW J. 1860 (1987); Martha Minow, Are Rights Right for Children?, 1987 AM. B. Found. RES. J. 203 (1987).

13. Reva Siegel, Why Equal Protection No Longer Protects: The Evolving Forms of StatusEnforcing State Action, 49 STAN. L. REv. 1111 (1997); Reva Siegel, "The Rule of Love": Wife Beating as Prerogative and Privacy, 105 YALE L.J. 2117 (1996).

14. See Siegel, supra note 1 at 1360.

15. See Ann Althouse, The People's Court, N.Y. Times Book Review, July 3, 2005, at Sec. 7 p. 8. ("Bill Clinton looked for consensus [judicial] nominees, because he tended to govern by merging divergent interests into triangulated solutions."). Some viewed this approach as abandoning his base. "If [George W. Bush] were Bill Clinton, you would expect him to "triangulate"-forsake his own base and reach out to the opposition, as Clinton did with NAFTA and welfare reform." See Robert Kutner, Bush's Imploding Presidency, Boston Globe, Oct. 29, 2005, at A19. Others treat it as deft combination to appeal to competing tastes. See Frank Bruni, An Elegan Stroll in Organ Clogs, N.Y. Times, Dec. 7, 2005, at Fl ("A Batali-Batsianich menu tends to prod diners in new directions without pushing them there, providing both moments of affirmation for the food snob and easy eating for the 
deliberation that emerges as much as compromise. Like modern commercial marketing, the advocate does not assume the listener already has settled preferences, but instead competes with rivals to plant and coax desires, to test which way to sell, and to undermine the appeal of alternatives.

This discussion may just be a definitional game about where to draw the line between law and politics. But for contrast, consider the more overtly legal form taken by communal dialogue in another constitutional democracy. Several months ago, while visiting Cambridge, Israeli Supreme Court Justice Ayala Procaccia described her court as engaged in a constant dialogue with the public through the media. ${ }^{16}$ Multiple news sources give daily criticism and debate of the court's work. The justices, in turn, each day read the critics. The court and the people, in this way, are continually and mutually informed. The justice also noted that her court addresses some 12,000 petitions per year, in a country with a population of seven million, many from the territories. She said she understands this as a kind of continuing exchange with the community. Through these many decisions, in the mode of a court of equity, the lsrael Supreme Court builds a stockpile of good will to be tapped when the court takes up a controversial issue, such as the constitutionality of interrogation measures.

Compare that workload with the eighty to ninety cases heard by our Supreme Court for our population of $\mathbf{2 4 5}$ million. With its relatively few decisions, our Court seems more like an oracle on high than a focal poimt for ongoing communal debate and consideration. This very comparison is no doubt too court-focused for Siegel, who wants to emphasize the avenues for constitutional culture that lie outside courts. But the judicial/nonjudicial distinction is not my point here. Instead, 1 mean to highlight how a contrasting institutional arrangement allows greater public focus on specifically legal interpretation not only in the exchange between the court and petitioners, but also in exchanges between the Israeli court and media, directly framing pressing issues for the public in terms of the legal debate.

What would be Siegel's response to this? She could say that a specifically legal constitutional culture emerges not only as competing groups internalize counterarguments, ${ }^{17}$ but also as the Supreme Court echoes debates between mobilized social movements. For women's rights advocates, this includes the development of intermediate into quasi-strict scrutiny for gender classifications under Fourteenth Amendment equal protection jurisprudence. ${ }^{18}$ First as a lawyer and then as a Justice, Ruth Bader Ginsburg not only symbolizes this development but directly transmits arguments she

food slacker. Mr. Batali and Mr. Bastianich have mastered in restaurants what Bill Clinton did in politics. They brilliantly triangulate.")

16. Remarks of Justice Ayala Procaccia, Harvard Law School, Cambridge, MA, Nov. 9, 2005.

17. Siegel, supra note 1 at 1406.

18. Craig v. Boren, 429 U.S. 190 (1976); United States v. Virginia, 518 U.S. 515 (1996). 
made as an advocate to the terms of the Supreme Court's opinion that she authored for the Court. Ginsburg's appointment, in turn, stems from the election of Bill Clinton, with Hillary as his co-campaigner. We can look at this as the "but-for" cause of Ginsburg's appointment itself, for it depended upon the profound cultural shifts in gender relations over the past 100 years. Cultural changes, technological, geo-political, and economic shifts each played a part, including the development and distribution of the contraceptive pill, two world wars, and global economic integration. All of these changes pulled more women into the paid labor force in order to support themselves and their families, and gave women both greater economic independence and further reasons to seek political and legal voice. All of these trends contributed to constitutional change and to the social movements pressing for it. ${ }^{19}$

Predictably, these achievements triggered successful countermovements. In the wake of gender struggles, we find various artifacts of failed reform, such as Geduldig v. Aiello, ${ }^{20}$ which treated pregnancy-based distinctions as non-sex based for constitutional purposes. Particularly poignant for me are two cases from my time clerking at the Court: 1) Michael M. v. Superior Court of Sunoma County, where the Court told us that gender differences in the pcnalties for sex with minors posed no constitutional problem, given the "real differences" between males and females; ${ }^{21}$ and 2) Rostker v. Goldberg, where the Court declared that excluding women from military draft registration is not a problem because military experts exclude women from combat. ${ }^{22}$ Depending on what happens in the next decade or so, we may come to view these cases as the scuff marks left on the way to scaling the mountain, or instead as the memorials to valiant but failed efforts of reform.

Maybe the most specific legal residue from the clash of social movements are the explicit efforts by Justice Scalia to encourage mass mobilization against gay rights. His may not be the first judicial opinion to become a fund-raising letter, but Justice Scalia's dissent in Lawrence v. Texas was ready for photocopying the day it was released. ${ }^{23}$ Siegel emphasizes this irony: when judges write opinions in the key of original intent, they actually jazz up current interest groups to assault judicial precedents. ${ }^{24}$ Once

19. These social, economic and political factors were factors that led the court, including Chief Justice Rehnquist, to go along with protections against gender discrimination, Siegel, supra note 1 at 1335. The resulting cultural shifts were well in evidence in the opposition to Robert Bork's nomination to the Supreme Court-and the backpedaling of the Reagan White House in response

20. 417 U.S. 484 (1974).

21. 450 U.S. 464 (1981).

22. 453 U.S. 57 (1981).

23. See Siegcl, supra note 1 at 1346 .

24. Id. at 1347. This raises another question for me: what precisely gives us cause to celebrate when the use of informal pathways to change constitutional culture produce talismanic phrases, like "unique physical characteristics" and "on account of sex," that move from judicial opinions to ordinary 
again, I wonder what makes this constitutionalism rather than out and out politics.

Perhaps the settings of politics turn debates over decriminalizing same-sex sodomy and gaining equality for women into "constitutional culture." Some feature of collective life converts abstract arguments into meanings and practices. This hypothesis leads to my second (and I promise shorter) question, investigating that feature: Reva, why not give more attention to the governance structures established by our Constitution, as you connect self-governance and constitutionalism? You set aside the institutional dimensions, at least for now. Yet the branches and levels of government forged by the Constitution seem essential to the contours of argument, persuasion, culture, and consciousness that you address. The disciplining effects of persuasion, internalizing the arguments of the opposition, are wonderfully evident in legislative compromise, as Jeremy Waldron emphasizes in his argument for legislative leadership (even if the actual Congress these days seems locked in the irons of challenger-proof districts and lobbyists' money). ${ }^{25}$ Your constitutional discourse rotates around the courts. But why not include the legislative orbit, and claim it for constitutional culture, as do Robin West, Mark Tushnet, Larry Kramer, Larry Sager, and Jeremy Waldron? ${ }^{26}$

Similarly, the other big structure designed by our constitutionfederalism-needs sharper relief if we are to assess how it complicates your story or confirms it. You note, but make little of, the fact that thirtyfive states embraced the ERA, promoting and reflecting transformed ideas of gender. The interpretation of those amendments at the state level provided - and still provides - many avenues for reconstituting society and self-government. Indeed, the ERA looks a lot more de jure at the state level. It is worth considering how that affects the federal level. The redundancy ${ }^{27}$ manifest in maintaining both levels of government affords more avenues for social movements, debates, dialogue, and all the stuff that makes for Siegelian constitutional culture. When Justice Brennan

argument? These phrases permeate diseussions far from courts, but why is this something to celebrate? Sueh phrases capture specialized locutions that summarize debates, and become technical terms that potentially limit the flow of conversation and effectiveness of legal advocacy.

25. Jeremy Waldron, The Dignity Of Legislation (1999); Jeremy Waldron, Law And DisAGREEMENT (1999).

26. See Larry Kramer, The People Themselves; Popular Constituitonalism and Judicial Review (2004); Lawrence G. Sager, Justice in Plain Clothes: A Theory Of american Constitutional Practice (2004); Mark Tushnet, Taking The Constitution Away From The Courts (1999); Lawrence Sager, The Domain of Constitutional Justice, in Constitutionalism: Philosophic Foundations 235 (Larry Alexander, ed. 1998); Robin West, The Aspirational Constitution, 88 Nw. U.L. Rev. 241 (1993); Waldron, supra n. 25. For a thoughtful treatment of these ideas, see James E. Fleming, Judicial Review Without Judicial Supremacy: Taking the Constitution Seriously Ouside the Courts, 73 FordH AM L. REv. 1377 (2005).

27. See Robert M. Cover, The Uses of Jurisdictional Redundancy: Interest, Ideology, and Innnovation, 22 WM. \& MARY L. REv. 639 (1981). 
suggested that state supreme courts may be the best hope for future protection of individual rights, ${ }^{28} \mathrm{I}$ do not think he meant that those courts were exclusively qualified for this task. Instead, they represent the legal pluralism etched by, and in turn replenishing, constitutional culture. Today, he might join those who look to the federal embrace of international conventions on women's rights as another arena of struggle and source of hope.

To acknowledge the legal pluralism embraced by and nourishing our constitutionalism, we should in fact consider settings beyond the formal federal and state duality. In the domestic arena, our Constitution contemplates settings beyond governmental institutions for both self-governance and public debate over values. It preserves the public and private spheresincluding religious communities, civil society, and nonprofit organizations, each of which have offered arenas for contesting gender-based status hierarchies and thus expressing and invigorating constitutional culture. In this broader landscape, losses at one level can motivate victories at another. Thus, the Supreme Court's rejection of an openly gay Boy Scout leader's antidiscrimination claim against the Boy Scouts-in the name of the Scouts' freedom of association-has produced amazing ricochet effects furthering gay rights. ${ }^{29}$ Churches and even military bases that used to give the Scouts a place to meet have closed their doors. Gay rights advocates have found sympathetic allies who would not otherwise have come forward had the Court ruled against the Scouts. With those local alliances comes a long-term change in consciousness. Struggles in religious communities for over gender equality and treatment of scxual minorities parallel those in the secular world. The interactions between these worlds amplify, and also complicate, Siegel's picture.

We could imagine constituting the relationships among these large and small scale spheres even more tightly to see how that would affect the dynamics of change. Consider the federalist system's emerging developments in international law. The International Criminal Court's (ICC) jurisdiction is directly cabined by the ability and willingness of member states to pursue the violations of human rights the court is meant to address. ${ }^{30}$ Such domestic actions will advance the movement for international law with highly visible indictments and trials in the ICC. But even more so, international criminal law will be strengthened by redress pursued at the domestic level by member states. Because the ICC itself cannot prosecute when the nation state takes up the task, ${ }^{31}$ the creation of the ICC gives new

28. William J. Brennan Jr., The Bill of Rights and the States: The Revival of State Constitutions as Guardians of Individual Rights, 61 N.Y.U. L. REV. 535 (1986).

29. Boy Scouts of America v. Dale, 530 U.S. 640 (2000).

30. Rome Statute of the International Criminal Court, July 17, 1998, 37 I.L.M. 999 (1998).

3I. For statement of the principle of complementarity, through which the Court defers to member states if those member states proceed with prosecutions within the Court's jurisdiction, see id., Preamble, Article I. 
leverage to advocates for change within nations. In fact, high profile international codes will be few if law and justice grow as hoped for at the member-state level, for the formal court is designed to promote the development of national level law and institutions to punish and deter genocide, crimes against humanity, and violations of human rights. What if we analogously understood American states, localities, religions, and nonprofit organizations, similarly, as sites for strengthened constitutional enforcement? Slender and maybe even failed efforts before the Supreme Court could trigger and signal something bigger and deeper going on in the states and in private realms. In any case, Siegel's constitutional culture does and must operate in the nooks and crannies of church basements, PTA meetings, private employers' flex time and day care programs; in the decision of a mayor to perform same-sex marriages; and in the capillaries of the body politic.

Hence, our constitution explicitly established governance structures in the distinct but coordinated branches and the dual sovereignty of state and national governments. The Constitution's substantive rights presumed and invigorated the private governance structures of voluntary associations, religions, corporations, charities, work places, and families. In these governance structures lies the answer to what makes the affiliations and deliberations of Siegel's social movements rightly identified as constitutional law. The people's informal work of persuasion and association through the means established or protected by the constitution is rightly called constitutional participation. By expressing themselves and responding to others in rallies, Internet chat rooms, letters to legislators; in local, state, and national settings; and in secular and religious communities, the people of this boisterous nation constitute ourselves. Explicit attention to the design and functioning of these channels would highlight reforms needed to enable participation by all the people.

I look forward to the dialogue Reva Siegel has initiated. In the wake of the confirmation of Chief Justice Roberts and Justice Alito to the Court, it is high time to remember Justice Brennan's comment: "It isn't just me and my moral commitments speaking; it is us." 32 How can the "us" give life to our Constitution? With Reva Siegel's map, we can, we will, and we must.

32. See Kathleen M. Sullivan, Epistemic Democracy and Minority Rights, 86 CALIF. L. REv. 445, 451 (1998) (quoting Justice Brennan). 
